\title{
PEMANFAATAN RPO (RED PALM OIL) SEBAGAI SUMBER PROVITAMIN A ALAMI PADA PRODUK MI INSTAN UNTUK ANAK BALITA
}

\author{
(The Use of RPO as A Sources of Natural Provitamin A in Instant Noodle Product for \\ Under Five Children)
}

\author{
Sri Anna Marliyati ${ }^{1 *}$, Hardinsyah ${ }^{1}$, dan Neysa Rucita ${ }^{1}$ \\ ${ }^{1 *}$ Alamat korespondensi: Departemen Gizi Masyarakat, Fakultas Ekologi Manusia, Institut Pertanian \\ Bogor, Bogor 16680. Telp: 0251-8621258; Fax: 0251-8622276; Email: anna_marliyati@yahoo.com \\ 1 Departemen Gizi Masyarakat, Fakultas Ekologi Manusia, Institut Pertanian Bogor, Bogor 16680.
}

\begin{abstract}
The objective of this research was to study the use of RPO as a sources of natural provitamin $A$ in instant noodle product for under five children. For this purpose 5 formulas were developed based on RPO's level added to the formula (0\%, 25\%, 50\%, 75\% and $100 \%)$. The result shown that instant noodle with 75\% RPO was the best formula of RPO instant noodle. No significant difference in acceptance between this formula and other commercial instant noodle ( $a>0.05)$. The result of RPO instant noodle's chemical analysis were moisture content $7.40 \%$ (wb), ash content $2.51 \%(d b)$, protein content $13.66 \%(d b)$, fat content $9.84 \%$ $(\mathrm{db})$, carbohydrate was $74.49 \%(\mathrm{db})$ and carotenoid $136.41 \mathrm{ppm}(\approx 76.42 \mathrm{ppm}$ B-carotene $\approx$ 636.8 RE/serving size). RPO instant noodle has physical properties as follow, optimum cooking time was 3 minutes, the color was yellow-red, elasticity properties was $261.94 \%$ $455.65 \%$ and water holding capacity was $137.98 \%$. This noodle was contributing $100 \%$ of vitamin A RDA for the children.
\end{abstract}

Keywords: Red palm oil, carotenoid, vitamin A deficiency, under five children.

\section{PENDAHULUAN}

Kurang Vitamin A (KVA) merupakan masalah kesehatan masyarakat di negara berkembang. WHO menyatakan bahwa KVA diderita oleh sekitar 40\% populasi dunia, terutama wanita hamil dan menyusui serta anak dibawah lima tahun. Kelompok umur yang rentan mengalami KVA adalah bayi usia 6 11 bulan dan anak balita usia 12-59 bulan. Diperkirakan sebanyak 100-140 juta anak masih mengalami KVA pada tingkat subklinis, meskipun defisiensi secara klinis mengalami penurunan. KVA dapat menyebabkan kegagalan dalam fungsi sistemik, yang dicirikan dengan kelainan perkembangan janin, anemia, dan lemahnya fungsi imun.

Hingga saat ini penanggulangan KVA dilakukan melalui beberapa cara yaitu suplementasi kapsul vitamin A dosis tinggi dan fortifikasi pangan. Namun, tidak selamanya penanggulangan KVA harus bergantung pada upaya tersebut mengingat fortifikan yang digunakan masih menggunakan vitamin A sintetik yang harus diimpor dari luar negeri. Oleh karena itu, perlu upaya lain untuk mendampingi dan menunjang upaya penanggulangan yang sudah ada sehingga penanganan KVA dapat lebih maksimal, yaitu dengan mengembangkan produk tinggi vitamin A atau provitamin A yang berasal dari sumber alami. Salah satu sumber provitamin A alami yang dapat digunakan adalah minyak sawit merah (Red Palm Oil - RPO) yang merupakan hasil pemurnian dari minyak sawit kasar (Crude Palm Oil - (PO). Selain ketersediaan minyak kelapa sawit yang melimpah di Indonesia, RPO juga memiliki kandungan vitamin A (dari Bkaroten) 15-30 kali lebih tinggi dibandingkan wortel dan tomat (Ball 1988).

Pangan yang potensial untuk difortifikasi adalah mi instan karena disukai, harganya terjangkau dan mudah didapat. Penambahan RPO dengan kandungan pro-vitamin A yang tinggi kedalam mi instan akan meningkatkan mutu mi instan dari segi gizi. Oleh sebab itu, perlu dilakukan penelitian lebih lanjut untuk mengembangkan produk $\mathrm{mi}$ instan dengan penambahan RPO agar dapat menghasilkan produk yang selain tinggi kandungan provitamin A juga dapat diterima khususnya oleh anak balita.

Tujuan umum dari penelitian ini adalah untuk mengkaji pemanfaatan Red Palm Oil (RPO) dari Crude Palm Oil (CPO) sebagai sumber provitamin A alami pada produk mi instan untuk anak balita. Adapun tujuan khusus dari penelitian ini adalah: 1) Menganalisis kandungan karotenoid, karakteristik fisik dan kimia 
RPO yang dibuat dari CPO; 2) Melakukan formulasi mi instan RPO secara tepat; 3) Menganalisis mutu organoleptik mi instan RPO; 4) Mempelajari daya terima mi instan RPO terpilih melalui uji organoleptik pada anak balita; 5) Menganalisis kandungan gizi dan karakteristik fisik dari mi instan RPO terpilih.

\section{METODE}

\section{Waktu dan Tempat}

Penelitian ini dilaksanakan pada bulan Mei 2009 sampai Oktober 2009. Tempat yang digunakan yaitu Laboratorium Pengolahan Pangan dan Laboratorium Kimia dan Analisis Pangan, Departemen Gizi Masyarakat, FEMA, IPB, Laboratorium Pilot Plan SEAFAST Center, IPB dan Laboratorium Teknopark Fateta, IPB.

\section{Bahan dan Alat}

Bahan utama yang digunakan adalah RPO dari hasil pemurnian CPO (berasal dari PT Multimas Nabati Asahan), bahan pembuat mi instan yaitu tepung terigu, garam, CMC (Carboxy Methyl Celullose), $\mathrm{K}_{2} \mathrm{CO}_{3}, \mathrm{Na}_{2} \mathrm{CO}_{3}$ dan air, serta bahan-bahan untuk analisis kimia.

Peralatan yang diperlukan adalah alat pembuat RPO (agigator, penangas, pompa vacum dan sentrifus), alat pembuat mi instan (seperangkat noodle maker dan cabinet dryer), serta alat-alat laboratorium untuk analisis kimia dan fisik.

\section{Tahapan Penelitian}

Penelitian diawali dengan menyiapkan RPO, yaitu melalui pemurnian CPO. Tahap pemurnian meliputi degumming (proses penghilangan gum dan pengotor lain pada (PO), netralisasi (pemisahan asam lemak bebas dengan cara penambahan basa), dan setrifugasi untuk memisahkan sabun yang terbentuk pada proses netralisasi. Fraksi yang digunakan sebagai RPO adalah fraksi olein (fraksi cair). Karakteristik kimia dan fisik RPO selanjutnya dianalisis.

Penambahan RPO pada mi instan didasarkan pada kebutuhan vitamin A sehari anak balita (450 RE). RPO mensubstitusi penggunaan minyak nabati dengan taraf substitusi 0\% (F0), 25\% (F25), 50\% (F50), 75\% (F75) dan 100\% (F100). Kelima formula selanjutnya diuji organoleptik pada 30 orang panelis semi terlatih. Pengujian dilakukan baik secara hedonik (warna, aroma, rasa, tekstur dan keseluruhan), maupun mutu hedonik (warna dan tekstur) terhadap mi instan tanpa kuah dan dengan kuah serta persentase pene- rimaannya dibandingkan dengan mi instan ko- mersial. Formula terpilih merupakan formula dengan persentase penerimaan keseluruhan tertinggi. Formula terpilih salanjutnya diuji penerimaanya pada 30 orang panelis anak 4-5 tahun. Selain itu, dilakukan pula analisis kandungan gizi (air, abu, protein, lemak, serat dan total karoten) dan fisik (cooking time, daya serap air, warna dan elongasi) terhadap formula terpilih tersebut.

\section{Rancangan Percobaan}

Rancangan percobaan yang digunakan untuk penelitian ini adalah Rancangan Acak Lengkap (RAL). Secara sistematis, bentuk umum dari rancangan tersebut adalah sebagai berikut:

Yij $=\mu+\tau_{i}+\epsilon_{i j}$

Keterangan :

Yij = Nilai pengamatan (warna, aroma, rasa, tekstur dan penerimaan keseluruhan) karena pengaruh taraf penambahan RPO kei pada ulangan ke-j.

$\mu=$ Nilai rata-rata umum.

$\tau_{i}=$ Pengaruh tingkat penambahan RPO terhadap mutu produk pada taraf ke-i.

$\varepsilon_{\mathrm{ij}}=$ Kesalahan penelitian karena pengaruh taraf penambahan RPO ke-i pada ulangan ke-j.

$\mathrm{i}=$ Taraf penambahan RPO.

$\mathrm{j}=$ Ulangan $(1,2,3,4,5, \ldots \ldots, 30)$.

\section{Pengolahan dan Analisis Data}

Data hasil ditabulasikan dan diolah menggunakan sidik ragam (one way ANOVA), bila berpengaruh nyata $(\alpha<0.05)$ dilanjutkan dengan uji Duncan. Penerimaan balita terhadap mi instan RPO dibandingkan dengan mi komersial dianalisis dengan uji non parametrik Friedman Test, sedangkan nilai kandungan gizi $\mathrm{mi}$ instan formula terpilih dianalisis secara deskriptif. Data diolah menggunakan program MS. Excel dan SPSS 16.0 for Windows.

\section{HASIL DAN PEMBAHASAN}

\section{Pemurnian Minyak}

Proses pemurnian minyak meliputi degumming, netralisasi dan sentrifugasi. Proses degumming mengacu pada hasil penelitian Widarta (2008), dimana $\mathrm{H}_{3} \mathrm{PO}_{4} 85 \%$ yang ditambahkan sebanyak $0.15 \%(\mathrm{~b} / \mathrm{b})$ dari berat 
minyak. Pada proses netralisasi digunakan $\mathrm{NaOH}$ dengan konsentrasi $11.1 \%$ (16 $\left.{ }^{\circ} \mathrm{Bé}\right)$ dan diaduk secara kontinyu selama 25 menit sambil dipanaskan pada suhu $\pm 59{ }^{\circ} \mathrm{C}$ (Mas'ud 2007). Kadar asam lemak bebas pada minyak direaksikan dengan basa, lalu sabun yang terbentuk dihilangkan dengan sentrifus. Sabun akan bercampur dengan fraksi stearin (fraksi padat) dibagian bawah tabung karena memiliki densitas yang lebih tinggi. Secara keseluruhan rendemen yang dihasilkan pada proses pemurnian ini adalah $80.9 \%$.

\section{Karakteristik Minyak}

Berikut adalah hasil analisis terhadap karakteristik fisik dan kimia dari CPO dan RPO yang digunakan.

Tabel 1. Karakteristik Fisik dan Kimia CPO dan RPO

\begin{tabular}{|c|c|c|}
\hline Parameter & CPO & RPO \\
\hline Warna & $\begin{array}{l}\text { Jingga } \\
\text { kemerahan }\end{array}$ & Merah \\
\hline ALB (\%) & 1.54 & 0.73 \\
\hline Kadar air (\%) & 0.10 & 0.06 \\
\hline $\begin{array}{l}\begin{array}{l}\text { Bilangan } \\
(\mathrm{mekv} / \mathrm{kg})\end{array} \\
\text { Peroksida }\end{array}$ & 3.41 & 2.81 \\
\hline Total karotenoid (ppm) & 660.00 & 2511.13 \\
\hline
\end{tabular}

Warna. Menurut BSN (2006), analisis warna pada CPO dilakukan secara visual. Hasil pengamatan menunjukkan bahwa CPO yang digunakan berwarna jingga kemerahan, sedangkan RPO yang dihasilkan berwana merah. Warna pada minyak sawit disebabkan oleh karotenoid yang terkandung di dalamnya (Ketaren 2008). Karotenoid merupakan persenyawaan hidrokarbon tidak jenuh yang bersifat larut dalam minyak. Oleh sebab itu, warna pada RPO (fraksi olein) lebih merah dibandingkan pada CPO karena karotenoid, terutama B-karoten, terkonsentrasi pada fraksi olein (fraksi cair) dibandingkan dengan fraksi stearin (fraksi padat).

Asam Lemak Bebas (ALB). Kadar ALB pada CPO adalah sebesar $1.54 \%$, sedangkan pada RPO nilainya mengalami penurunan menjadi $0.73 \%$. Penurunan terjadi karena ALB pada CPO bereaksi dengan basa yang ditambahkan dan membentuk sabun. Berdasarkan hasil tersebut dikatakan proses netralisasi yang dilakukan cukup efektif mereduksi kandungan ALB minyak.
Kadar air. Kadar air CPO yang digunakan sebesar $0.10 \%$, sedangkan pada RPO sebesar $0.06 \%$. Kedua nilai tersebut lebih rendah dari yang disyaratkan BSN (2006) yaitu kadar air maksimal $0.5 \%$. Kadar air RPO lebih rendah dari CPO karena saat netralisasi terbentuk emulsi antara air dan minyak juga karena adanya pengaruh proses penyaringan.

Bilangan peroksida. Peroksida adalah bahan kimia yang dapat mempercepat oksidasi atau sebagai bahan pengoksidasi. Bilangan peroksida CPO cukup rendah yaitu sebesar 3.41 mekv/kg, sedangkan RPO $2.81 \mathrm{mekv} / \mathrm{kg}$. Nilai ini lebih rendah dari bilangan peroksida CPO pada penelitian Mas'ud (2007) dan Puspitasari (2008) yang secara berturut-turut nilainya 5.1 mekv/kg dan 5.3 mekv/kg. Nilia bilangan peroksida CPO dan RPO rendah diduga karena kandungan antioksidan di dalamnya. Van Stuijvenberg (2001) menyatakan bahwa RPO kaya akan tokoferol dan tokotrienol yang merupakan antioksidan kuat, dimana keduanya dapat melindungi minyak dari kerusakan oksidatif.

Total karoten. Kadar karotenoid CPO adalah sebesar $660 \mathrm{ppm}$, sedangkan RPO sebesar $2511.13 \mathrm{ppm}$. Komponen karotenoid utama pada minyak sawit adalah a- dan Bkaroten, yang nilainya secara berturut-turut adalah 35.16\% dan 56.02\% (Basiron 2005). Kandungan B-karoten CPO dan RPO berturutturut adalah 369.73 ppm dan 1406.7 ppm. Nilai ini tidak jauh berbeda dengan kandungan vitamin A RPO yang dinyatakan oleh Passmore dan Eastwood (1986) dalam Ball (1988), yaitu sebesar $30.000 \mathrm{RE} / 100 \mathrm{~g}$ RPO. Beta-karoten pada RPO lebih tinggi karena karoten termasuk pigmen yang larut pada minyak, sehingga banyak terkonsentrasi pada fraksi olein. Oleh sebab itu nilainya menjadi lebih tinggi pada RPO daripada CPO.

\section{Formulasi Mi Instan RPO}

Kandungan karoten pada RPO digunakan sebagai acuan dalam formulasi mi instan dan disesuaikan dengan kebutuhan vitamin A balita sehari (450 RE). Batas bawah formula adalah syarat suatu jenis makanan untuk dapat diklaim sebagai sumber zat gizi tertentu, yaitu memenuhi 15\% AKG. Batas atas adalah penambahan minyak pada adonan $\mathrm{mi}$, yaitu sebesar 10\% (b/b) dari terigu. Berikut adalah komposisi bahan yang digunakan pada berbagai formula mi instan. (Tabel 2) 
Tabel 2. Formula Mi Instan RPO

\begin{tabular}{lrrrrr}
\hline \multirow{2}{*}{ Bahan } & \multicolumn{5}{c}{ Berat Bahan (g) } \\
\cline { 2 - 6 } & F0 & F25 & F50 & F75 & F100 \\
\hline Terigu & 100 & 100 & 100 & 100 & 100 \\
Minyak & 10.0 & 7.5 & 5.0 & 2.5 & 0.0 \\
RPO & 0.0 & 2.5 & 5.0 & 7.5 & 10.0 \\
Garam & 1.5 & 1.5 & 1.5 & 1.5 & 1.5 \\
$\mathrm{~K}_{2} \mathrm{CO}_{3}$ & 0.2 & 0.2 & 0.2 & 0.2 & 0.2 \\
$\mathrm{Na}_{2} \mathrm{CO}_{3}$ & 0.2 & 0.2 & 0.2 & 0.2 & 0.2 \\
$\mathrm{Air}$ & 36.0 & 36.0 & 36.0 & 36.0 & 36.0 \\
$\mathrm{CMC}$ & 1.0 & 1.0 & 1.0 & 1.0 & 1.0 \\
\hline Total adonan & 148.9 & 148.9 & 148.9 & 148.9 & 148.9 \\
\hline Estimasi kandungan Vitamin A (RE) & 0 & 249.1 & 498.2 & 747.3 & 996.4 \\
\hline
\end{tabular}

Mi instan yang dibuat tidak menggunakan metode penggorengan tetapi menggunakan metode pengeringan udara panas. Tujuannya adalah untuk menghindari rusaknya karoten oleh panas dan larutnya karoten pada minyak penggoreng, sehingga dikhawatirkan akan memperbesar kehilangan karoten pada mi. Pembuatan mi diawali dengan proses pencampuran bahan. Terigu yang digunakan adalah terigu protein tinggi (11-13\%). Garam dan alkali $\left(\mathrm{Na}_{2} \mathrm{CO}_{3}\right.$ dan $\left.\mathrm{K}_{2} \mathrm{CO}_{3}\right)$ dilarutkan terlebih dahulu agar ketiga bahan tersebut dapat berdisosiasi merata dalam adonan. Bahan cair ditambahkan sedikit demi sedikit dan berselingan dengan penambahan minyak. CMC digunakan sebagai bahan pengembang, tujuannya adalah untuk memperbaiki ketahanan terhadap air dan mempertahankan keempukan selama penyimpanan. Selanjutnya adalah pembentukan lembaran mi untuk menghaluskan serat-serat gluten. Penggilingan adonan menjadi bentuk lembaran dilakukan berkalikali (7-10 kali) sampai lembaran terbentuk sempurna. Selanjutnya lembaran dipotongpotong menjadi bentuk mi. Tahap berikutnya adalah pemasakan yang meliputi pengukusan selama 10 menit dan pengeringan. Proses pengeringan dilakukan selama \pm 1.5 jam pada suhu $60-70{ }^{\circ} \mathrm{C}$ tujuannya untuk menurunkan kadar air mi. Rendemen mi yang dihasilkan adalah $77.6 \%$.

\section{Sifat Organoleptik}

Sifat organoleptik mi diuji pada 30 panelis semi terlatih, yaitu mahasiswa tingkat akhir Departemen Gizi Masyarakat, FEMA, IPB. Berikut disajikan hasil uji organoleptik dari masing-masing komponen organoleptik (Tabel 3).

Warna. Hasil uji mutu hedonik menunjukkan nilai rataan warna mi instan RPO berkisar antara 2.81-7.50, yaitu sangat pucat (F0) sampai kuning (F100). Seiring dengan mening- katnya penambahan RPO maka semakin tinggi nilai rataan warnanya, hal ini berarti warna mi akan semakin kuning. RPO memiliki warna kuning kemerahan karena kandungan karotenoid di dalamnya, RPO yang digunakan mengandung karotenoid 2511.13 ppm. Hasil uji statistik menunjukkan terdapat perbedaan nyata pada warna mi instan $(\alpha<0.05)$. Uji Duncan menunjukkan setiap formula berbeda nyata satu sama lain. Berarti substitusi RPO pada berbagai taraf mempengaruhi penampakan warna mi instan.

Hasil uji kesukaan (hedonik) menunjukkan rata-rata tingkat kesukaan mi tanpa kuah adalah 3.25-6.02, yaitu tidak suka (F0) hingga agak suka (F75). Pada mi kuah nilai rataannya 4.17-5.90, agak tidak suka (F0) hingga biasa (F75). Berdasarkan hasil uji statistik substitusi RPO pada berbagai taraf memberikan pengaruh yang nyata $(\alpha<0.05)$. F75 memiliki nilai penerimaan tertinggi yaitu sebesar $63.3 \%$ (tanpa kuah) dan $66.7 \%$ (kuah). Nilai ini lebih rendah dibandingkan dengan penerimaan mi instan komersial (73.3\%). Mi instan komersial umumnya diberi pewarna buatan pada saat pembuatannya sehingga berwarna agak kekuningan. Pada kelima formula, warna kuning berasal dari RPO yang selain sebagai sumber provitamin A juga dapat berfungsi sebagai pewarna alami makanan.

Tekstur. Hasil uji mutu hedonik tekstur, menunjukkan mi instan RPO memiliki nilai rataan 3.83 (F0)-5.10 (F75), yaitu tidak elastis hingga cenderung agak elastis. Jumlah minyak yang terkandung pada setiap formula uji sama (10\% b/b tepung). Partikel minyak yang terdistribusi dalam adonan akan menghambat penetrasi air saat pemasakan dan akan memperlambat proses gelatinisasi granula pati pada mi, sehingga mi menjadi kurang elastis (Niihara et al. 1996). Berdasarkan hasil uji statistik tidak terdapat perbedaan tekstur yang nyata pada setiap formula mi $(a>0.05)$. 
Tabel 3. Persentase Panelis yang Menerima Mi Instan RPO

\begin{tabular}{|c|c|c|c|c|c|c|c|c|c|c|c|c|}
\hline \multirow{2}{*}{$\begin{array}{l}\text { Atribut } \\
\text { Mutu }\end{array}$} & \multicolumn{6}{|c|}{ Tanpa Kuah } & \multicolumn{6}{|c|}{ Kuah } \\
\hline & F0 & F25 & F50 & F75 & F100 & Kom & F0 & F25 & F50 & F75 & F100 & Kom \\
\hline Warna & 6.7 & 43.3 & 46.7 & 63.3 & 60.0 & 56.7 & 16.7 & 43.3 & 63.3 & 66.7 & 63.3 & 73.3 \\
\hline Tekstur & 33.3 & 53.3 & 50.0 & 66.7 & 50.0 & 80.0 & 30.0 & 46.7 & 43.3 & 56.7 & 50.0 & 90.0 \\
\hline Aroma & 30.0 & 36.7 & 43.3 & 40.0 & 56.7 & 76.7 & 70.0 & 70.0 & 66.7 & 66.7 & 70.0 & 86.7 \\
\hline Rasa & 56.7 & 36.7 & 33.3 & 40.0 & 46.7 & 73.3 & 46.7 & 63.3 & 63.3 & 46.7 & 70.0 & 93.3 \\
\hline Keseluruhan & 33.3 & 53.3 & 50.0 & 66.7 & 50.0 & 80.0 & 46.7 & 70.0 & 21.0 & 70.0 & 66.7 & 93.3 \\
\hline
\end{tabular}

Keterangan : $\mathrm{TK}=$ Tanpa Kuah, $\mathrm{K}=$ Kuah, Kom= Mi komersial

Hasil uji hedonik menunjukkan penerimaan tekstur mi berkisar 4.29-5.62, yaitu agak tidak suka (F0) hingga biasa (F75). Pada mi instan dengan kuah nilai rataan berkisar antara 4.32-5.19, agak tidak suka (F0) hingga biasa (F75). Hasil uji statistik menunjukkan substitusi RPO tidak berpengaruh nyata terhadap tekstur mi ( $a>0.05)$. F75 memikili penerimaan tekstur tertinggi yaitu $66.7 \%$ (tanpa kuah) dan $56.7 \%$ (kuah), sedangkan yang terendah adalah F0 (33.3\%). Penerimaan tekstur mi komersial lebih tinggi dari kelima mi RPO yaitu sebesar $90 \%$.

Aroma. Rata-rata tingkat kesukaan aroma mi tanpa kuah berkisar 4.77-5.19 (agak tidak suka-biasa), sedangkan mi kuah 5.435.92 (biasa). Hasil uji statistik menunjukkan substitusi RPO hingga taraf maksimum tidak memberikan pengaruh nyata pada aroma mi $(a>0.05)$. Pada tabel 3 dapat dilihat aroma F100 paling banyak disukai panelis, 70\% (kuah). Penerimaan aroma mi komersial lebih tinggi dibanding kelima formula mi RPO. Hal ini karena pada mi komersial, mi dikeringkan dengan metode penggorengan sehingga aromanya menjadi lebih khas.

Rasa. Nilai rataan kesukaan panelis terhadap rasa mi tanpa kuah berkisar 4.37 (F50)-5.30 (F0) (agak tidak suka-biasa), hasil yang serupa juga diperoleh mi kuah 4.84 (FO)5.67 (F100). Hasil uji statistik menunjukkan substitusi RPO hingga taraf maksimum yang diujikan (10\% berat tepung) tidak memberikan pengaruh nyata terhadap rasa $\mathrm{mi}$ instan $(a>0.05)$. Penerimaan panelis pada mi instan tanpa kuah bumbu tidak terlalu tinggi $(<50 \%)$. Penerimaan panelis terhadap rasa mi instan meningkat ketika mi instan diberi kuah. Pemberian kuah berpengaruh positif terhadap penerimaan rasa mi karena akan menutupi rasa yang tidak disukai pada mi. Penilaian tertinggi adalah pada formula F100 $(70 \%)$. Penerimaan kelima formula mi lebih rendah dari mi instan komersial (93.3\%).
Keseluruhan. Secara keseluruhan ratarata tingkat kesukaan mi RPO tanpa kuah berkisar 4.61 (F0)-5.48 (F75) (agak tidak suka sampai biasa), sedangkan $\mathrm{mi}$ dengan kuah 4.87-5.81 (agak tidak suka sampai biasa). Hasil uji statistik menunjukkan tidak terdapat perbedaan nyata pada tingkat kesukaan keseluruhan kelima formula mi $(\alpha>0.05)$. Penerimaan mi dengan kuah lebih baik dibandingkan tanpa kuah. F25 dan F75 disukai lebih banyak panelis dibandingkan formula lain. Kandungan vitamin A F75 (747.3 RE) lebih tinggi dibanding F25 (249.1 RE). Selain itu, F75 memiliki penerimaan tertinggi pada dua atribut lain (warna dan tekstur). Berdasarkan pertimbangan tersebut dipilihlah F75 sebagai formula terbaik.

\section{Uji Penerimaan pada Balita}

Formula terpilih diujikan pada 30 orang anak 4-5 tahun yang berasal dari TK Alif Balebak (20 orang) dan TK ABC Sindang Barang Jero (10 orang). Atribut yang dinilai adalah penerimaan mi secara keseluruhan. Nilai yang diberikan meliputi suka, biasa dan tidak suka. Bersama dengan mi instan RPO diujikan pula mi instan komersial sebagai pembanding. Berikut adalah tabel hasil penilaian mi instan RPO oleh anak balita (Tabel 4).

Berdasarkan hasil uji diketahui sebanyak $80 \%$ panelis menyukai mi instan RPO, sedangkan penerimaan pada mi instan komersial sedikit lebih tinggi yaitu $86.7 \%$. Berdasarkan hasil uji non parametric Friedman diketahui bahwa tidak terdapat perbedaan yang nyata $(\alpha>0.05)$ antara penerimaan mi instan RPO dan mi komersial. Suatu formula makanan tambahan untuk anak dapat diterima atau tidak jika: (1) Jumlah presentase anak yang menolak makanan tersebut kurang dari $25 \%$ dan (2) anakanak mampu mengkonsumsi makanan tersebut (Winarno, 1987 dalam Muchtadi, 1994). Mi instan RPO dikatakan dapat diterima karena sudah memenuhi kriteria tersebut, yaitu persentase yang menolak mi RPO sebesar 10\% $(<25 \%)$ dan mi dapat dikonsumsi dengan baik oleh anak. 
Tabel 4. Hasil Uji Penerimaan Mi Instan Panelis Balita

\begin{tabular}{lllll}
\hline \multirow{2}{*}{ Daya Terima } & \multicolumn{2}{r}{ Mi RPO } & \multicolumn{2}{c}{ Mi Komersial } \\
\cline { 2 - 5 } & $\Sigma$ & $\%$ & $\Sigma$ & $\%$ \\
\hline Suka & 24 & 80 & 26 & 86.7 \\
Biasa & 3 & 10 & 2 & 6.7 \\
Tidak Suka & 3 & 10 & 2 & 6.7 \\
\hline
\end{tabular}

\section{Sifat Fisik Mi}

Cooking time. Menurut BSN (2000) cooking time mi instan maksimum adalah 3 menit. Pada penelitian ini mi instan yang dibuat memiliki cooking time 3 menit. Nilai ini telah memenuhi syarat SNI mengenai waktu maksimum pemasakan mi instan. Penentuan cooking time penting dilakukan untuk menghasilkan tekstur mi matang yang diinginkan. Kim (1996) menyatakan bahwa tekstur mi yang diinginkan adalah kenyal, sedangkan tekstur yang tidak dikendaki adalah terlalu lembek seperti bubur.

Warna. Warna mi dianalisis menggunakan alat Chromameter Minolta CR 300. Hasil analisis warna mi instan RPO menunjukkan nilai $\mathrm{Hue}^{\circ}$ sebesar 88.5 - 88.6, yang menunjukkan kisaran warna kuning-merah (yellow-red). Hal ini karena adanya penambahan RPO pada $\mathrm{mi}$ instan tersebut. RPO mengandung karotenoid yang berwarna kuning kemerahan, sehingga penambahannya pada $\mathrm{mi}$ instan akan mempengaruhi penampakan fisik mi instan.

Elongasi. Elongasi memenggambarkan kemampuan mi untuk merenggang (memanjang) dari ukuran awal pada saat menerima tekanan dari luar. Mi instan RPO memiliki elongasi antara $261.94 \%-455.65 \%$, sedangkan $\mathrm{mi}$ komersial 381.96\%-533.20\%. Berdasarkan nilai rataan diketahui elongasi mi instan RPO adalah 76\% dari elongasi mi instan komersial, artinya terdapat perbedaan sebesar $24 \%$. Perbedaan ini diduga merupakan pengaruh penambahan RPO terhadap mi instan formula uji. Menurut Niihara (1996), minyak yang ditambahkan pada adonan akan menghambat penyerapan air saat pemasakan (rehidrasi), sehingga menghambat proses gelatinisasi granula pati. Hal inilah yang menyebabkan turunnya kualitas elastisitas mi.

Daya Serap Air (DSA). DSA menunjukkan kemampuan mi untuk menyerap air secara maksimal selama proses pemasakan. Mi instan RPO memiliki DSA sebesar $137.98 \%$. Nilai ini tidak jauh berbeda dengan mi instan terigu biasa yaitu sebesar $138.60 \%$ (Indriani 2005). Semakin tinggi nilai DSA, semakin banyak air yang mampu diserap oleh mi dan mi semakin mengembang.

\section{Sifat Kimia Mi}

Kadar air. BSN (2000) mensyaratkan kadar air mi instan dengan metode pengeringan udara panas maksimal adalah $14.5 \%$. Mi instan yang dibuat pada penelitian ini memiliki kadar air sebesar $7.4 \%$. Nilai ini menunjukkan bahwa mi instan RPO masih memenuhi syarat. Air pada mi sebagian besar menguap saat mi dikeringkan.

Kadar abu. Kadar abu secara kasar menggambarkan kandungan mineral bahan pangan. Mi instan RPO memiliki kadar abu sebesar 2.01\% (bk), sedangkan pada mi instan komersial sebesar $2.51 \%$. Menurut Kim (1996) kandungan abu mi instan tergantung pada kandungan abu pada tepung terigu sebagai bahan utamanya dan jumlah garam serta alkali yang ditambahkan pada adonan mi.

Kadar protein. Sumber protein pada mi instan RPO terutama berasal dari tepung terigu. Tepung terigu yang digunakan adalah jenis hard flour, dengan kandungan protein 1213\%. Menurut BSN (2000) kandungan protein mi instan terigu minimal $8 \%$. Pada penelitian ini kandungan protein $\mathrm{mi}$ instan RPO adalah $13.66 \%$ (bk). Nilai ini cukup tinggi bahkan melebihi standar SNI.

Kadar lemak. Kadar lemak yang dianalisis adalah kadar lemak kasar menggunakan metode ekstraksi soxhlet. Total penambahan minyak pada mi RPO adalah sebesar $10 \mathrm{~g}$ per $100 \mathrm{~g}$ tepung. Kandungan lemak minyak kelapa sawit adalah sebesar 98\% (Depkes 2004), sehingga secara teoritis kadar lemak pada adonan mi instan RPO adalah sebesar 9.8\% (bb). Berdasarkan hasil analisis, kadar lemak mi instan RPO adalah sebesar 9.12\% (bb). Nilai ini tidak jauh berbeda dengan hasil perhitungan teoritis. Nilai yang lebih rendah tersebut diduga karena adanya kehilangan selama proses pembuatan mi.

Kadar karbohidrat. Perhitungan kadar karbohidrat dilakukan dengan metode by difference yaitu dengan cara mengurangi 100\% dengan total komponen gizi lainnya (kadar air, abu, protein, dan lemak). Berdasarkan hasil perhitungan tersebut diperoleh kadar karbohidrat mi instan RPO sebesar $74.49 \%$ (bk). Sumber karbohidrat pada mi ini berasal dari teung terigu yang digunakan dan berhubungan erat dengan kandungan pati di dalamnya.

Berikut adalah tabel hasil analisis kandungan gizi mi instan RPO dan mi instan komersial (Tabel 5). 
Tabel 5. Data Kandungan Gizi Mi Instan RPO dan Mi Komersial

\begin{tabular}{lcccc}
\hline Zat Gizi & \multicolumn{3}{c}{ Mi RPO } & $\begin{array}{c}\text { Mi Komersial * } \\
\text { (\% bk) }\end{array}$ \\
\cline { 2 - 4 } Kadar air & bb & \% bk & 9.60 \\
Kadar abu & 7.40 & - & 2.51 \\
Protein & 1.86 & 2.01 & 12.78 \\
Lemak & 12.65 & 13.66 & 18.02 \\
Karbohidrat & 9.12 & & 9.84 & \\
Karoten (ppm) & 68.97 & & 74.49 & \\
\hline K & & 136.41 & & \\
\hline
\end{tabular}

* Sumber: Indriani (2005)

Total karoten. Analisis karoten pada produk mi instan dilakukan dengan metode spektrofotometri dengan panjang gelombang $a=450 \mathrm{~nm}$. Berdasarkan hasil analisis, kandungan karoten mi instan RPO adalah sebesar $136.41 \mathrm{ppm}(\approx$ B-karoten $=76.42 \mathrm{ppm})$. Kehi langan B-karoten selama proses pembuatan mi instan adalah sebesar $17.9 \%$. Kondisi pengolahan yang dapat menurunkan kandungan Bkaroten mi instan RPO adalah proses pengeringan pada suhu $60-70^{\circ} \mathrm{C}$ selama \pm 1.5 jam.

\section{Kontribusi Mi Terhadap Kebutuhan Vitamin A}

Kandungan karoten pada mi instan RPO yang diperoleh dari hasil analisis digunakan untuk menghitung tingkat kecukupan vitamin A anak balita (450 RE/hari). Kandungan Bkaroten $\mathrm{mi}$ adalah sebesar $76.42 \mathrm{ppm}$ atau setara dengan vitamin A 12.74 RE. Kandungan vitamin A mi instan per takaran saji (50 g) adalah sebesar 636.8 RE, nilai ini dapat memenuhi $100 \%$ kebutuhan vitamin A anak balita sehari. Produk mi instan RPO ini dapat dikatakan sebagai pangan sumber provitamin A karena kandungan vitamin A di dalamnya memenuhi lebih dari 15\% AKG yang dianjurkan.

\section{KESIMPULAN}

Hasil anaisis fisik dan kimia RPO yang dibuat yaitu berwarna merah dengan kadar ALB sebesar $0.73 \%$, kadar air $0.06 \%$, bilangan peroksida 2.81 mekv/kg dan kandungan karotenoid sebesar 2511.13 ppm. Berdasarkan hasil analisis ini RPO yang dihasilkan tergolong baik karena memiliki nilai ALB, kadar air dan bilangan peroksida yang rendah. Hal ini menunjukkan belum terjadi kerusakan pada RPO tersebut.

Berdasarkan uji organoleptik terpilihlah formula F75 sebagai formula yang paling disukai karena memiliki nilai penerimaan tertinggi. Persentase penerimaan mi instan RPO pada panelis anak balita adalah sebesar $80 \%$.
Tidak terdapat perbedaan penerimaan yang nyata antara mi instan RPO dengan mi instan komersial ( $a>0.05)$.

Kandungan gizi mi instan RPO antara lain kadar air 7.4\% (bb), kadar abu 2.01\% (bk), protein $13.66 \%$ (bk), lemak $9.84 \%$ (bk) dan karbohidrat sebesar $74.49 \%$ (bk). Formula F75 memiliki kandungan karotenoid sebesar $136.41 \mathrm{ppm}$ (76.42 ppm B-karoten), yang setara dengan vitamin A sebesar 636.8 RE per kemasan (50 g). Nilai ini dapat memenuhi $100 \%$ kebutuhan vitamin A balita per hari. Kehilangan B-karoten selama proses pembuatan mi adalah sebesar $17.9 \%$. Hasil analisis sifat fisik mi yaitu cooking time 3 menit, warna mi kuning-merah, elongasi 261.94\%-455.65\% dan DSA 137.98\%.

Pemanfaatan RPO baik untuk dikonsumsi langsung maupun ditambahkan pada makanan dapat digunakan untuk mencegah terjadinya KVA, memenuhi kebutuhan vitamin A dan juga dapat digunakan sebagai pangan darurat yang bergizi di daerah bencana. Perlu diteliti lebih lanjut mengenai kehilangan vitamin A pada produk mi instan RPO setelah rehidrasi dan uji daya cerna vitamin A pada tubuh. Selain itu perlu pula dilakukan penelitian lanjutan mengenai pengaruh lama penyimpanan terhadap nilai gizi, sifat fisik dan sifat organoleptik mi instan RPO.

\section{DAFTAR PUSTAKA}

Ball G. 1988. Fat Soluble Vitamin Assays in Food Analysis. Elsevier Science, USA.

Basiron Y. 2005. Palm Oil. In Shahidi F (Ed.), Bailey's Industrial Oil and Fat Products. A John Wiley \& Sons, Inc. Vol. 6(2),333420.

[BSN] Badan Standarisasi Nasional. 2000. Mi Instan. SNI 01-3551-2000. Badan Standardisasi Nasional, Jakarta. 
[BSN] Badan Standarisasi Nasional. 2006. Crude Palm Oil. SNI 01-2901-2006. Badan Standardisasi Nasional, Jakarta.

[Depkes] Departemen Kesehatan. 2004. Daftar Komposisi Bahan Makanan. Depkes, Jakarta.

Hasrini RF. 2008. Inesterifikasi Enzimatik dengan Lipase pada Campuran Minyak Sawit Merah dan Minyak Kelapa untuk Menghasilkan Bahan Baku Spreads Kaya B-karoten . Tesis Sekolah Pascasarjana, IPB, Bogor.

Indriani S. 2005. Desain Proses Pembuatan dan Formulasi Mie Instan dari Campuran Tepung Sorghum (Sorghum Bicolor L.), Pati Jagung dan Gluten Terigu. Skripsi Sarjana Fakultas Teknologi Pertanian, $\mathrm{IPB}$, Bogor.

Ketaren S. 2008. Minyak dan Lemak Pangan. Universitas Indonesia Pr, Jakarta.

Kim SK. 1996. Instant Noodles. In Kruger JE, Matsuo RB dan Dick JW (Eds.), Pasta and Noodle Technology. American Association of Cereal Chemists, Inc., USA.
Mas'ud F. 2007. Optimasi Proses Deasidifikasi untuk Meminimalkan Kerusakan Karotenoid dalam Pemurnian Minyak Sawit. Disertasi Sekolah Pascasarjana, IPB, Bogor.

Muchtadi D. 1989. Evaluasi Nilai Gizi Pangan. Direktorat Pendidikan Tinggi, Departemen Pendidikan dan Kebudayaan, Pusat Antar Universitas Pangan dan Gizi, IPB, Bogor.

Niihara R, Yonezawa D dan Matsuo RR. 1996. Role of Lipids on Pasta and Noodle Quality. In Kruger JE, Matsuo RB dan Dick JW (Eds.), Pasta and Noodle Technology. American Association of Cereal Chemists, Inc., USA.

Van Stuijvenberg ME et al. 2001. The effect of a biscuit with red palm oil as a source of $B$-carotene on the vitamin A status of primary school children: a comparison with B-carotene from a synthetic source in a randomized controlled trial. Eur $\mathrm{J}$ Clin Nutr, 55, 657-662.

Widarta IWR. 2008. Kendali Proses Deasidifikasi dalam Pemurnian Minyak Sawit Merah Skala Pilot Plant. Disertasi Program Pascasarjana, IPB, Bogor. 